\title{
Lipid raft-based membrane order is important for antigen-specific clonal expansion of $\mathrm{CD}^{+} \mathrm{T}$ lymphocytes
}

\author{
Daniel Schieffer ${ }^{1,2}$, Sanya Naware ${ }^{1,3}$, Walter Bakun $^{1}$ and Anil K Bamezai ${ }^{*}$
}

\begin{abstract}
Background: Lipid rafts are cholesterol and saturated lipid-rich, nanometer sized membrane domains that are hypothesized to play an important role in compartmentalization and spatiotemporal regulation of cellular signaling. Lipid rafts contribute to the plasma membrane order and to its spatial asymmetry, as well. The raft nanodomains on the surface of $\mathrm{CD}^{+} \mathrm{T}$ lymphocytes coalesce during their interaction with antigen presenting cells (APCs). Sensing of foreign antigen by the antigen receptor on $\mathrm{CD}^{+} \mathrm{T}$ cells occurs during these cell-cell interactions. In response to foreign antigen the $\mathrm{CD}^{+} \mathrm{T}$ cells proliferate, allowing the expansion of few antigen-specific primary $\mathrm{CD}^{+} \mathrm{T}$ cell clones. Proliferating $\mathrm{CD} 4^{+} \mathrm{T}$ cells specialize in their function by undergoing differentiation into appropriate effectors tailored to mount an effective adaptive immune response against the invading pathogen.

Results: To investigate the role of lipid raft-based membrane order in the clonal expansion phase of primary $\mathrm{CD}^{+} \mathrm{T}$ cells, we have disrupted membrane order by incorporating an oxysterol, 7-ketocholesterol (7-KC), into the plasma membrane of primary CD4 ${ }^{+} \mathrm{T}$ cells expressing a T cell receptor specific to chicken ovalbumin ${ }_{323-339}$ peptide sequence and tested their antigen-specific response. We report that 7-KC, at concentrations that disrupt lipid rafts, significantly diminish the c-Ovalbumin ${ }_{323-339}$ peptide-specific clonal expansion of primary CD4 ${ }^{+} \mathrm{T}$ cells.
\end{abstract}

Conclusions: Our findings suggest that lipid raft-based membrane order is important for clonal expansion of $\mathrm{CD}^{+} \mathrm{T}$ cells in response to a model peptide.

Keywords: Lipid rafts, Membrane order, CD4+ T cells, Clonal expansion, Cholesterol, 7-ketocholesterol, Fluorescence resonance energy transfer

\section{Background}

Spatial distribution of signaling molecules/receptors within the plasma membrane and their re-organization during cellular interaction appears to be important for responses generated by immune and non-immune cells [1-7]. While asymmetry in the plasma membrane is intrinsic because of the distribution of lipids that harbor either positive or negative charge [8-12], the compositionally heterogeneous lipid rafts [13-19] contribute to membrane asymmetry, as well. Lipid rafts are enriched in saturated lipids, lipid-anchored proteins including ones with glycosylphosphatidyl-linkage, and cholesterol [20-24]. The distribution of cholesterol in the membrane

\footnotetext{
*Correspondence: anil.bamezai@villanova.edu

'Department of Biology, Villanova University, 800 Lancaster Avenue,

Villanova, PA 19085, USA

Full list of author information is available at the end of the article
}

and compositional heterogeneity of lipid rafts generates lipid raft-dependent membrane order and spatial asymmetry on the plasma membrane. Ways to disrupt lipid raft-based membrane order and molecular asymmetry in the membrane and assess its consequence on cellular responses have not been fully tested.

$\mathrm{CD}_{4}^{+} \mathrm{T}$ cells play a central role in orchestrating the adaptive immune response in vertebrates. The antigen receptor on $\mathrm{CD}^{+} \mathrm{T}$ cells recognizes a specific antigen being displayed via the Major Histocompatibility Complex $(\mathrm{MHC})$ on the surface of antigen presenting cells (APC) $[25,26]$. A number of other accessory cell proteins with co-stimulatory function provide additive or synergistic signaling [27]. All these signaling proteins congregate at the contact site of the two interacting cells and form an immunological synapse [28,29]. Lipid rafts with their cargo are recruited to this site [30-35]. These early 
membrane events unleash signaling cascades that result in activation of three key transcriptional factors, namely NFAT, NFkB, and AP-1, which in turn drive transcription of, among others, the gene for $\mathrm{T}$ cell growth factor, IL-2. T cell growth factor-dependent clonal expansion of $\mathrm{CD}^{+} \mathrm{T}$ cells is key to the cell-mediated adaptive immune response to a foreign antigen. It is during this phase that the $\mathrm{CD}_{4}^{+} \mathrm{T}$ cells differentiate in response to intrinsic (cell-autonomous) and extrinsic (non-cell autonomous signaling initiated by cytokines derived from cells of innate immunity) factors into Th1, Th2, Th17 or $\mathrm{T}_{\text {reg }}$ effector $\mathrm{T}$ cells for generating effective immunity against invading pathogens.

A number of signaling receptors, ion channels and cell signaling proteins are sequestered in lipid rafts [36-40], but the role of these cholesterol-rich nanodomains in $\mathrm{CD}^{+}{ }^{+} \mathrm{T}$ cell signaling has remained unclear. One mechanism through which lipid rafts may contribute to cell signaling in $\mathrm{CD}^{+} \mathrm{T}$ cells is by promoting dynamic asymmetry in the plasma membrane and allowing interactions between signaling proteins as the sub-populations of nano-domains, each housing signaling proteins, coalesce $[2,41]$. Recently we have observed that the initial contact between the CD4 ${ }^{+} \mathrm{T}$ cell and the APC, in the absence of a specific antigen, promotes lipid raft coalescence [42]. However, the role of lipid raft-based membrane order in clonal expansion of primary $\mathrm{CD}^{+} \mathrm{T}$ cells in response to a specific foreign antigen is not fully examined.

One approach to assess the role of lipid raft-based order in cell signaling is by disrupting the membrane order, either by removing cholesterol from these nanodomains or inserting raft-destabilizing molecules in them. $M \beta C D$, a compound that binds cholesterol and destabilizes lipid rafts, and has been used to assess the role of lipid rafts during the early phase of cell signaling $[43,44]$. However, the effectiveness of this compound at high concentrations over a short incubation period (15 min) and its adverse effects on internal $\mathrm{Ca}^{2+}$ stores has raised concerns over its use [45-47]. Therefore to test the role of lipid raft-based order in $\mathrm{CD}^{+} \mathrm{T}$ cell response, we have inserted a naturally occurring oxysterol, $7-\mathrm{KC}$, into the plasma membrane of $\mathrm{CD}^{+} \mathrm{T}$ cells to disrupt the lipid raft-dependent order. Incorporation of 7 -KC with its ketone group at the $7^{\text {th }}$ position of the sterol ring disrupts the liquid ordered $\left(\mathrm{I}_{\mathrm{o}}\right)$ phase of model membranes and promotes formation of liquid disordered $\left(I_{d}\right)$ phase [41]. We have examined the role of lipid raftbased membrane order in clonal expansion of $\mathrm{CD}_{4}^{+} \mathrm{T}$ cells after inserting 7-KC into the membrane and disrupting the membrane order. Our results show that disruption of lipid raft-dependent membrane order with incorporation of $7-\mathrm{KC}$ in the membrane negatively impacts antigen-specific clonal expansion of primary $\mathrm{CD}_{4}^{+}$ T cells.

\section{Methods}

Mice

We used DO.11 TCR $\alpha \beta$ transgenic (a generous gift from Dr. Dennis Loh) [48] and Balb/c mice. Mice were housed at Villanova University vivarium with active sentinel program in accordance with approved internal IACUC protocols and guidelines. Research involving mice reported in the manuscript was approved by institutional IACUC committee as per guidelines set up by the Office of Laboratory Animal Welfare (OLAW) at National Institutes of Health.

\section{Purification of $\mathrm{CD}^{+} \mathrm{T}$ cells}

Lymph nodes were dissected from mice and single cell suspension was generated by gently crushing them between frosted glass slides and harvesting in wash medium made with RPMI 1640 supplemented with 5\% fetal bovine and $2 \mathrm{mM}$ HEPES buffer (Invitrogen-Life Technologies, Grand Island, NY). CD4 ${ }^{+}$T cells were negatively selected from total LN cell preparations using magnetic beads according to the manufacturer's protocol (Invitrogen-Life Technologies, Grand Island, NY).

\section{Antigen presenting cells (APCs)}

Autologous spleen cells from Balb/c mice were used as a source of APCs. A single cell suspension generated from spleen was treated with Tris-ammonium chloride for 7 minutes at $37^{\circ} \mathrm{C}$ to lyse red blood cells. Spleen cells devoid of RBC were washed with wash media (RPMI 1640 supplemented with $5 \%$ fetal bovine serum and $2 \mathrm{mM}$ HEPES) and re-suspended in culture media with cOva $323-339$ peptide for presentation to $\mathrm{CD} 4^{+} \mathrm{T}$ cells.

\section{Cell culture}

Lymph node cells or purified DO.11 $\mathrm{CD}^{+} \mathrm{T}$ cells were cultured in the presence or absence of $\mathrm{COva}_{323-339}$ peptide (Sigma Genosys, Woodlands, TX). In some co-cultures syngeneic APC's from Balb/c mice were included. To assess the proliferation of CD4 ${ }^{+} \mathrm{T}$ cells, lymph node cells or purified $\mathrm{CD}^{+}{ }^{+} \mathrm{T}$ cells were labeled with CFSE (Molecular Probes-Life Technologies, Grand Island, NY) prior to their addition to the co-cultures as per previously published protocols with some modification [49]. Briefly, CFSE staining was carried out with $5 \times 10^{6}$ cells at $600 \mathrm{nM}$ final concentration in $1 \mathrm{ml}$ volume for 10 minutes, with gentle shaking at ambient temperature. The staining was quenched by adding two volumes of ice cold wash media followed by incubation on ice for five minutes. The cells were pelleted by centrifugation and the washing step was repeated twice to remove excess CFSE dye. Cells were then re-suspended in culture media consisted of RPMI 1640 supplemented with $10 \%$ FBS, $2 \mathrm{mM}$ of non-essential amino acids, $50 \mathrm{I} . \mathrm{U} / \mathrm{ml}$ penicillin and $50 \mu \mathrm{g} / \mathrm{ml}$ streptomycin and $1 \mu \mathrm{g} / \mathrm{ml}$ fungizone, $2 \mathrm{mM}$ HEPES (Invitrogen-Life Sciences, 
Grand Island, NY). $5 \times 10^{5}$ CFSE labeled lymph node cells or $1 \times 10^{5}$ CFSE-labeled $\mathrm{CD} 4^{+} \mathrm{T}$ cells were cultured with either the control $\mathrm{cOva}_{324-334}$ or stimulatory $\mathrm{COva}_{323-339}$ peptide at $1 \mu \mathrm{M}$ final concentration of the peptide for $72 \mathrm{hrs}$ at $37^{\circ} \mathrm{C}$ in a $5 \% \mathrm{CO}_{2}$ incubator. For cultures with purified $\mathrm{CD} 4^{+} \mathrm{T}$ cells, $2.5 \times 10^{5}$ syngeneic APC were added to present specific peptide. Additional co-cultures were set up with $\mathrm{CD}^{+}{ }^{+} \mathrm{T}$ cells that were not labeled with CFSE to serve as a control for analysis by flow cytometer.

\section{Treatment of cells with 7-keto cholesterol (7-KC) and methyl $\beta$ cyclo-dextrin ( $M \beta C D$ )}

7-KC and $\mathrm{M} \beta C D$ complexes were generated and incorporated into the plasma membrane by following a previously published protocol [50]. Briefly, cells were treated with a mixture of an appropriate concentration of 7-KC (Sigma-Aldrich, St-Louis, MO) ranging from $70 \mu \mathrm{M}$ to $17.5 \mu \mathrm{M}$ and a fixed concentration $(0.3 \mathrm{mM})$ of $\mathrm{M} \beta \mathrm{CD}$ (Sigma-Aldrich, St-Louis, MO). 7-KC-M $\beta C D$ complexes were added to the co-culture either at the beginning of the culture (time $=0$ ) or after $5 \mathrm{~min}, 120 \mathrm{~min}$ or $24 \mathrm{hrs}$ of initiating the co-cultures. $\mathrm{m} \beta \mathrm{CD}-7-\mathrm{KC}$ complexes effectively targets $7-\mathrm{KC}$ to the plasma membrane, but low concentration $(0.3 \mathrm{mM})$ of $\mathrm{M} \beta \mathrm{CD}$ does not disrupt lipid rafts [50]. In some experiments 7-KC-m $\beta C D$ complexes were incubated with either lymph node cells or purified $\mathrm{CD}_{4}^{+} \mathrm{T}$ cells for 15 minutes and unbound complexes were washed twice by adding excess of wash media and centrifuging the cells. This unique experimental design allowed us to specifically examine effects of $7-\mathrm{KC}$ on lymph node or $\mathrm{CD}^{+} \mathrm{T}$ cell membrane at higher concentrations without effects on cellular viability.

\section{Flow cytometry}

Cultured cells were split and one half of cell cultures were labeled with anti-CD4-PE (BioLegend, San Diego, $\mathrm{CA})$ to enumerate proliferating $\mathrm{CD} 4^{+} \mathrm{T}$ cells and the other half was incubated with propidium Iodide (PI) (BD Biosciences, East Rutherford, NJ, USA) to assess the viability of cells as per previously published procedures from our laboratory [49]. Labeled and unlabeled (CFSE/ anti-CD4-PE/PI) cells were analyzed by FACS Calibur flow cytometer (BD Biosciences, East Rutherford, NJ, USA) using CellQuestPro software. Moreover, cell cultures set-up with CFSE-labeled lymph node or purified $\mathrm{CD}^{+}{ }^{+} \mathrm{T}$ cells but left untreated (absence of control and stimulatory c-Ova peptide and 7-KC) were used for setting up the quadrant gate to enumerate non-proliferating cells (upper right quadrant). For assessing the effect of peptide and 7-KC on CFSE-labeled cells, CFSE ${ }^{\text {highest }}$ nonproliferating cells present in the upper right quadrant were enumerated as it provides estimation of fraction of cells that did not undergo proliferation as opposed to cells that had undergone symmetrical and non-symmetrical cell division. Statistical significance between the 7-KC treated and untreated groups was determined by oneway analysis of variance tests using JMP software program. The Bonferroni procedure was then completed to determine which means were significantly different from the untreated groups.

\section{FRET}

To assess proximity of two proteins present within the lipid raft on the plasma membrane we carried out FRET analyses. Cells were labeled with a combination of acceptor antibody-conjugated fluorophore, anti-Thy-1-Alexa647 (FL3) (BD Biosciences, Franklin Lakes, NJ, USA), either in combination with donor antibody-conjugated fluorophore, anti-CD3e mAb-PE (FL2) (eBiosciences, San Diego, CA, USA) or anti CD71-PE (FL2) (BD Biosciences, Franklin Lakes, NJ, USA) for 60 minutes on ice. Cells were washed twice with $1 \mathrm{ml}$ of ice cold $0.1 \mathrm{M} \mathrm{PBS}$ and re-suspended in $250 \mu \mathrm{l}$ of ice cold PBS for FRET analysis with a FACSCalibur flow cytometer (BD Biosciences, Palo Alto, CA) as per previously published procedures [51] with modifications described here. Donor fluorophore (anti-CD3e-PE) was excited by $488 \mathrm{~nm}$ argon laser. Donor emission was detected in FL2 channel (575BP). Compensations were set up with donor-only labeled cells resulting in absence of detection for the donor emission in FL3 channel (620BP). Acceptor-only labeled cells were used to set up background and compensation for FL3 channel resulting in absence of observable emission detected in this channel when excited by $488 \mathrm{~nm}$ laser. Emission from the donor and acceptor fluorophore double labeled cells was used to enumerate FRET- positive events, where the emission from the donor (PE) when excited by $488 \mathrm{~nm}$ in turn excited the acceptor (AlexaFluor 647). The emission from the acceptor fluorphore was detected in FL3 channel. Cells left unlabeled were used to set-up the negative control gates of the quadrant to assess FRET positive events.

\section{Staining with Di-4-ANEPPDHQ}

Membranes of isolated lymph node cells were stained with di-4-ANEPPDHQ (Invitrogen-Life Technologies, Grand Island, $\mathrm{NY}$ ) at $0.5 \mu \mathrm{M}$ final concentration for $20 \mathrm{~min}$ at room temperature as suggested by the vendor and previously published protocols [52]. Cells were co-stained with anti-CD90-AlexaFluor 647 and analyzed by FACSCalibur flowcytometer (BD Biosciences, East Rutherford, NJ, USA) using $488 \mathrm{~nm}$ and $630 \mathrm{~nm}$ (Red) excitation lasers. Emission from these flourophores was measured at wavelengths 570 (FL2 channel), 630 (FL3 channel) and 670 (FL4 channel) after appropriate compensation set-up to allow the detection of specific flourophore. To specifically assess the membrane order of $\mathrm{T}$ cells, Anti-CD90AlexaFluor $647^{+}$cells were gated for their assessment of Di-4-ANEPPDHQ staining (FL2 Vs FL3). 


\section{Results}

\section{7-KC disrupts membrane rafts reversibly}

To begin to investigate the role of membrane order in clonal expansion of $\mathrm{CD}^{+} \mathrm{T}$ cells we first sought to examine whether $7-\mathrm{KC}$ did indeed disrupt the integrity of lipid rafts on the plasma membrane. To accomplish this, we designed an antibody FRET experiment for which we used a FRET pair of an AlexaFluor 647conjugated antibody against the membrane raft marker Thy1 (acceptor) and a PE conjugated antibody against CD3e, a component of TCR/CD3 signaling complex (donor). While Thy-1 is known to reside in lipid rafts, the TCR $\alpha \beta / C D 3$ complex is also present in these nanodomains $[17,42]$. In the absence of either the donor (anti-CD3e PE - FL2 channel) or the acceptor (antiThy-1-AlexaFluor647 - FL3 channel) we did not observe cells with productive FRET signal (upper right quadrant) (Figure 1A, controls 1 \& 2) by flow cytometer. These negative control experiments were used to set up the gates to enumerate cells with productive FRET signal (events in the upper right quadrant of the two color histogram). To examine the productive FRET signal we stained primary $\mathrm{CD}^{+} \mathrm{T}$ cells with anti-CD3e PE and
anti-Thy1-AlexaFluor-647. (Figure 1, no 7-KC group). Productive FRET signal in these cells is indicated by detection of emission from AlexaFluor647 (cells in upper right quadrant). Exposure of $\mathrm{CD}^{+} \mathrm{T}$ cells to $7-\mathrm{KC}$ diminished the number of cells with productive FRET signal. Inhibition of FRET signals by incorporating 7-KC in the membrane was dependent on the dose of $7-\mathrm{KC}$, with a strong FRET quenching observed at $70 \mu \mathrm{M}$ of $7-\mathrm{KC}$ ( $>90 \%$ inhibition) and low ( $50 \%$ quenching observed with $17.5 \mu \mathrm{M} 7$ - KC (Figure $1 \mathrm{~A}$ and $\mathrm{C}$ ). To examine the specificity of inhibition by $7-\mathrm{KC}$ we performed a control FRET experiments with anti-CD71 (anti-transferrin receptor), a non-raft marker. CD71 protein is homogenously distributed along the plasma membrane, but excluded from lipid rafts [53]. As expected, we did not observe significant alterations in number of cells emitting FRET signals between CD71-PE and Thy1-AlexaFluor647 in either the presence or absence of $7-\mathrm{KC}$ (Figure $1 \mathrm{~B}$ and C) at all the 7-KC concentrations tested. Quantitatively the FRET signal was similar to the background FRET with either the donor only (anti-CD3e-PE) or acceptor (Thy-1 AlexaFluor647) only fluorophore (Figure 1, control 1 and Control 2 groups). These control experiments were also

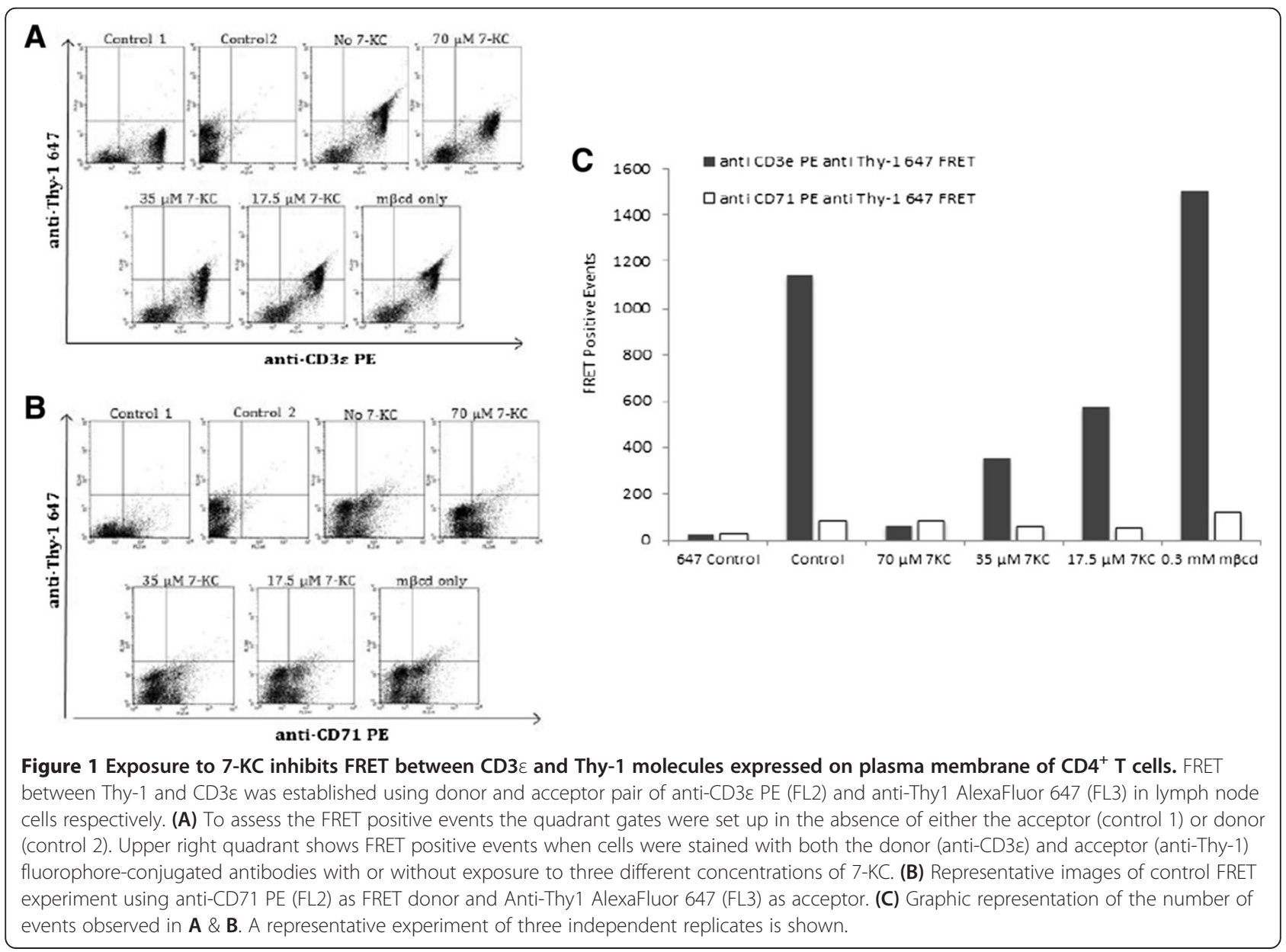


used to establish appropriate gates to set up the thresholds to quantify FRET positive cells (Figure 1A).

We next sought to examine if this disruption of lipid raft-based membrane order was reversible. To test that we carried out antibody FRET on $\mathrm{CD}_{4}^{+} \mathrm{T}$ cells previously exposed to 7-KC after their culture under cholesterol-rich culture conditions (culture media with 10\% FBS) for 20 hrs. The FRET signal was restored in cells re-exposed to cholesterol during the 20 hour incubation period (Figure 2). $\mathrm{CD}^{+} \mathrm{T}$ cells that were not exposed to $7-\mathrm{KC}$ and cultured under similar culture conditions served as controls and showed a strong FRET signal (Figure 2). These data indicate that the effects of $7-\mathrm{KC}$ on the plasma membrane are reversible with almost complete restoration of the membrane order after 20 hours and therefore suggesting the dynamic nature of these nanodomains. Taken together, these data suggest that the addition of $7-\mathrm{KC}$ to the $\mathrm{T}$ cell membrane specifically prevents interaction between the two raft molecules, Thy 1 and CD $3 \varepsilon$ in a reversible way.

To assess alterations in membrane fluidity by $7-\mathrm{KC}$ we chose di-4-ANEPPDHQ dye, this dye senses the membrane order and reports it on FL2 (570 nm) and FL3 $(630 \mathrm{~nm})$ channels when excited by $488 \mathrm{~nm}$ laser $[52,54]$. Figure 2 shows that gated $\left(\right.$ Thy $\left.-1^{+}\right)$lymph node $\mathrm{T}$ cells (Figure 3A) showed altered membrane order after their exposure to $7-\mathrm{KC}$ in a concentration dependent manner (Figure 3C-E) when compared to the untreated cell controls (Figure 3B). Alterations of membrane order by $7-\mathrm{KC}$ were significant, the highest effect was observed at two higher concentrations of $7-\mathrm{KC}(70 \mu \mathrm{M} \& 35 \mu \mathrm{M})$ (Figure 3B-E \& G). The observed effect of 7-KC was specific as the cells treated with $\mathrm{m} \beta C D$ vehicle control (Figure 3F \& G) did not show alterations in membrane order when compared to cells that were left untreated (Figure 3B \& G). Taken together these data are consistent with the FRET data and suggest that $\mathrm{CD}^{+} \mathrm{T}$ cell membranes exposed to $7-\mathrm{KC}$ alter membrane order.

\section{T cell activation and proliferation is disrupted by 7-KC without altering viability of these cells}

To examine the role of lipid raft-based membrane order in antigen-specific clonal expansion, lymph node cells from DO11 TCR transgenic mice were first labeled with CFSE followed by incubation with different concentrations of 7-KC along with either a stimulatory peptide c-OVA ${ }_{323-339}$, a control c-OVA $324-334$ peptide or stimulatory anti-CD3 $\varepsilon$ monoclonal antibody. Proliferation of $\mathrm{CD}^{+} \mathrm{T}$ cells in the culture was examined by FACS after staining with antiCD4 antibody to enumerate $\mathrm{CD}^{+}{ }^{+} \mathrm{T}$ cells. Day- 3 cultures also were stained with propidium iodide to assess viability of cells in these cultures. Whole range of concentrations for 7-KC was assessed for its effect on cell viability (data not shown). Based on these initial experiments $35 \mu \mathrm{M}$ and lower concentrations of 7-KC was used for the experiments here. Figure 4A shows that $35 \mu \mathrm{M} 7-\mathrm{KC}$ showed a significant inhibition of $\mathrm{CD} 4^{+} \mathrm{T}$ cell proliferation induced

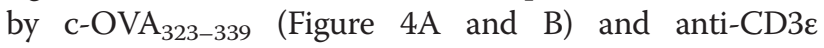
(Figure $4 \mathrm{C}$ ). In the presence of non-stimulatory peptide $\mathrm{cOVA}_{324-334}$ (Figure 4A and B) or anti-CD3e (Figure 4C) about $90 \%$ cells expressed non-dividing phenotype $\left(\mathrm{CD}_{4}^{+}\right.$ CFSE $^{\text {highest }}$ cells in upper right quadrant), as expected. In contrast, as many as $45 \%$ or $76 \%$ of cells had not undergone cell division $\left(\mathrm{CD} 4^{+} \mathrm{CFSE} \mathrm{Fighest}^{\text {h }}\right.$ ) in the presence of specific stimulatory peptide or anti-CD3 $\varepsilon$ mAb respectively. Minimal inhibition was observed in the presence of $17.5 \mu \mathrm{M} 7-\mathrm{KC}$ as only $17.3 \%$ and $41.2 \%$ non-dividing $\mathrm{CD}^{+}$ CFSE ${ }^{\text {highest }} \mathrm{T}$ cells remained in the cultures stimulated with

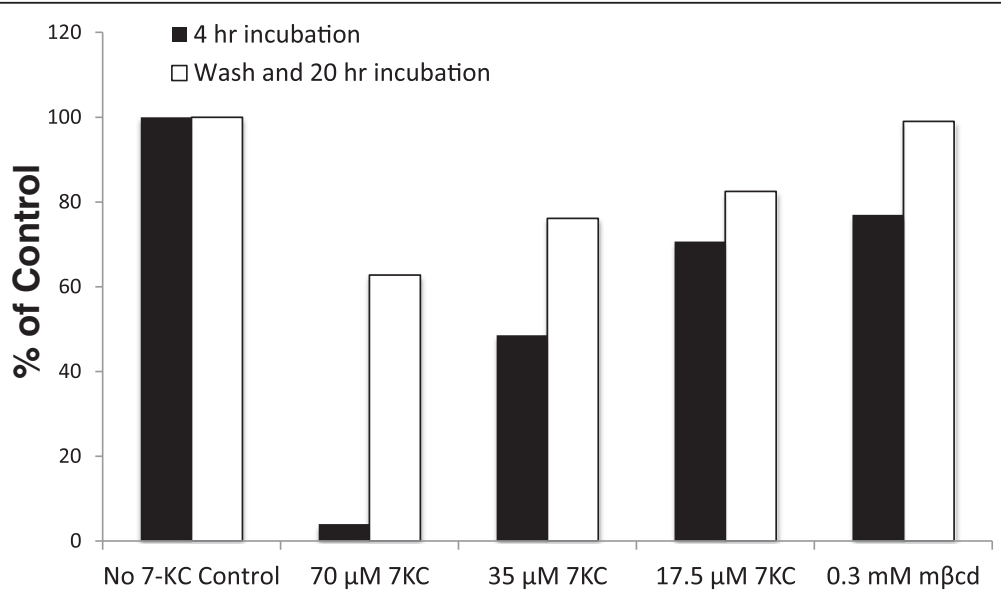

Figure 2 Reversibility of effects of 7-KC on abolishing FRET between Thy-1 and CD3 $\varepsilon$ present on membrane rafts on CD4 ${ }^{+} \mathrm{T}$ cells from

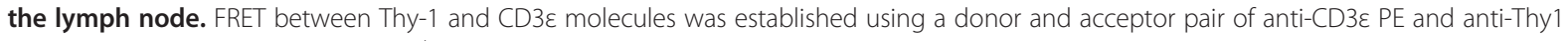
AlexaFluor 647 respectively after $\mathrm{CD}^{+}$cells were treated with a range of 7-KC concentrations for 4 hrs or left untreated. Reversibility of FRET was assessed after washing excess 7-KC and re-culturing cells for an additional 20 hrs. A representative experiment of three independent replicates is shown. 

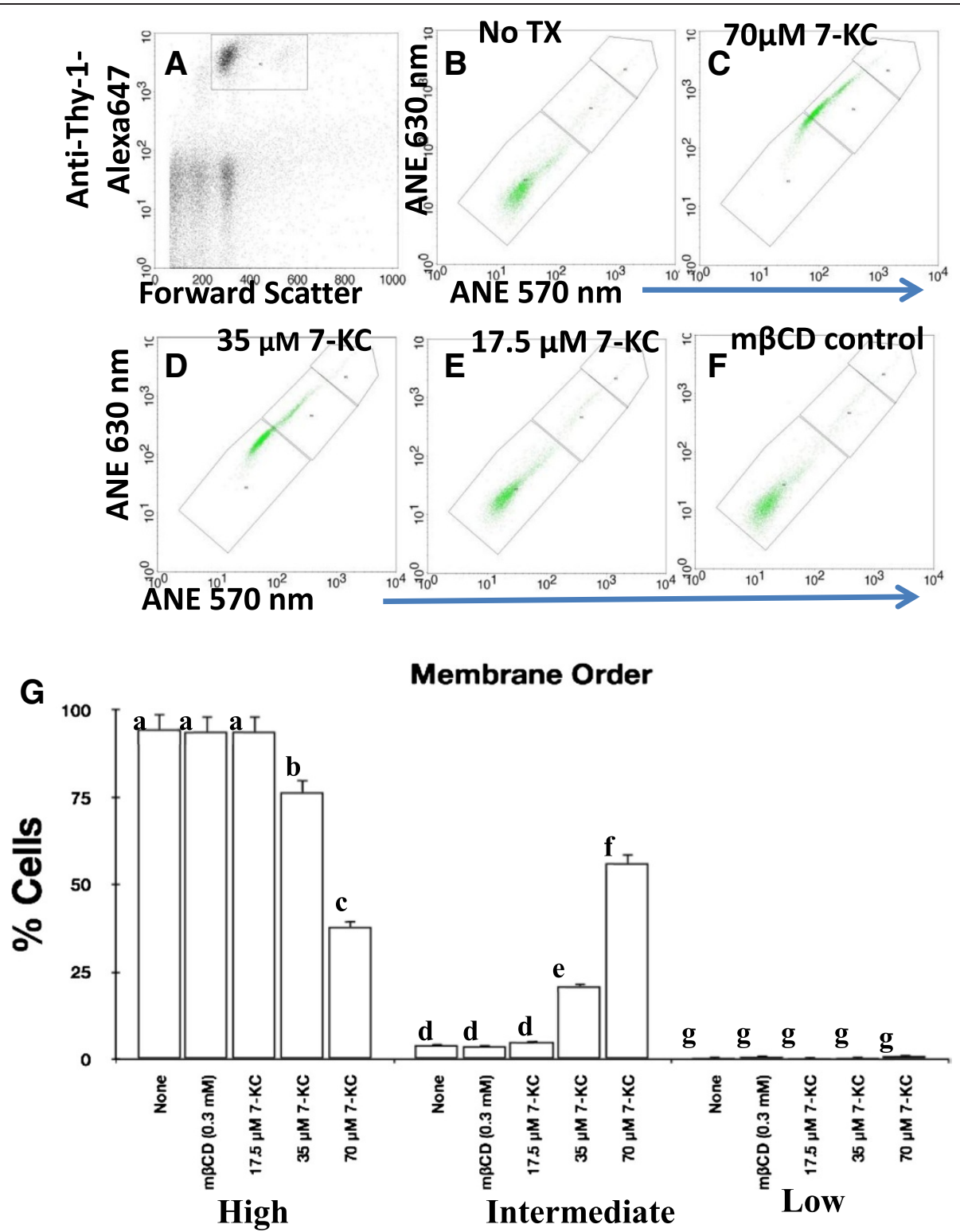

Figure 3 Exposure to 7-KC alters membrane order in $\mathrm{CD}^{+} \mathbf{T}$ cells. Lymph node cells were exposed to di-4 ANEPPDHQ dye and stained with anti-Thy-1 AlexaFluor 647. T cells treated with $70 \mu \mathrm{M}$ (C), $35 \mu \mathrm{M}$ (D), $17.5 \mu \mathrm{M}$ (E), mßCD-vehicle control (F) or left untreated (B) were gated (A) for Thy-1+ (FL4) and assessed for emission at $570 \mathrm{~nm}$ (FL2 channel) and $630 \mathrm{~nm}$ (FL3 channel) after appropriate compensation. T cells with high (lower most gate in B-F panels), intermediate (middle gate in B-F panels) and low (higher most gate in B-F panels) membrane order were enumerated and graphic representation of percent cells from four independent experiments with high, intermediate and low membrane order is shown in (G). Statistical significance between untreated, 7-KC treated groups was computed by two way ANOVA using JMP program. Different lower case alphabet designations $(\mathrm{a}-\mathrm{g}$ ) above each treatment group (none/untreated, $\mathrm{m} \beta C D, 17.5 \mu \mathrm{M}, 35 \mu \mathrm{M}, 70 \mu \mathrm{M} 7 \mathrm{KC}$ ) indicates statistically significant difference $(p<0.0001)$ within the group of cells with high or intermediate or low membrane order. Similar lower case alphabet designation indicates lack of statistical significance ( $p>0.8371)$.

$\mathrm{cOva}_{323-339}$ and anti-CD3ع respectively (Figure $4 \mathrm{~A}$ and $\mathrm{B}$ ). In contrast, we observed clonal expansion of untreated $\mathrm{CD}^{+}{ }^{+} \mathrm{T}$ cells and $\mathrm{CD} 4^{+} \mathrm{T}$ cells treated with vehicle control $(\mathrm{m} \beta \mathrm{CD})$ only in the presence of $\mathrm{COva}_{323-339}$ (Figure 4A and $\mathrm{B}$ ) or anti-CD3 $\varepsilon$ antibody (Figure $4 \mathrm{C}$ ), as expected. Only 21\% (for cOva $323-339$ stimulated cultures) and 31\% (for anti-CD3 $\varepsilon$ stimulated cultures) of day- $3 \mathrm{CD}^{+} \mathrm{T}$ cells had not undergone cell division. To examine the downstream effects of altered membrane order we next examined the effects of $7-\mathrm{KC}$ on cytokine production. $\mathrm{CD}_{4}^{+}$ $\mathrm{T}$ cells exposed to $7-\mathrm{KC}$ showed reduced IFN- $\gamma$ production and these effects were directly proportional to the concentration of $7-\mathrm{KC}$ treatment over the three day period (Additional file 1: Figure S1). Highest inhibition 


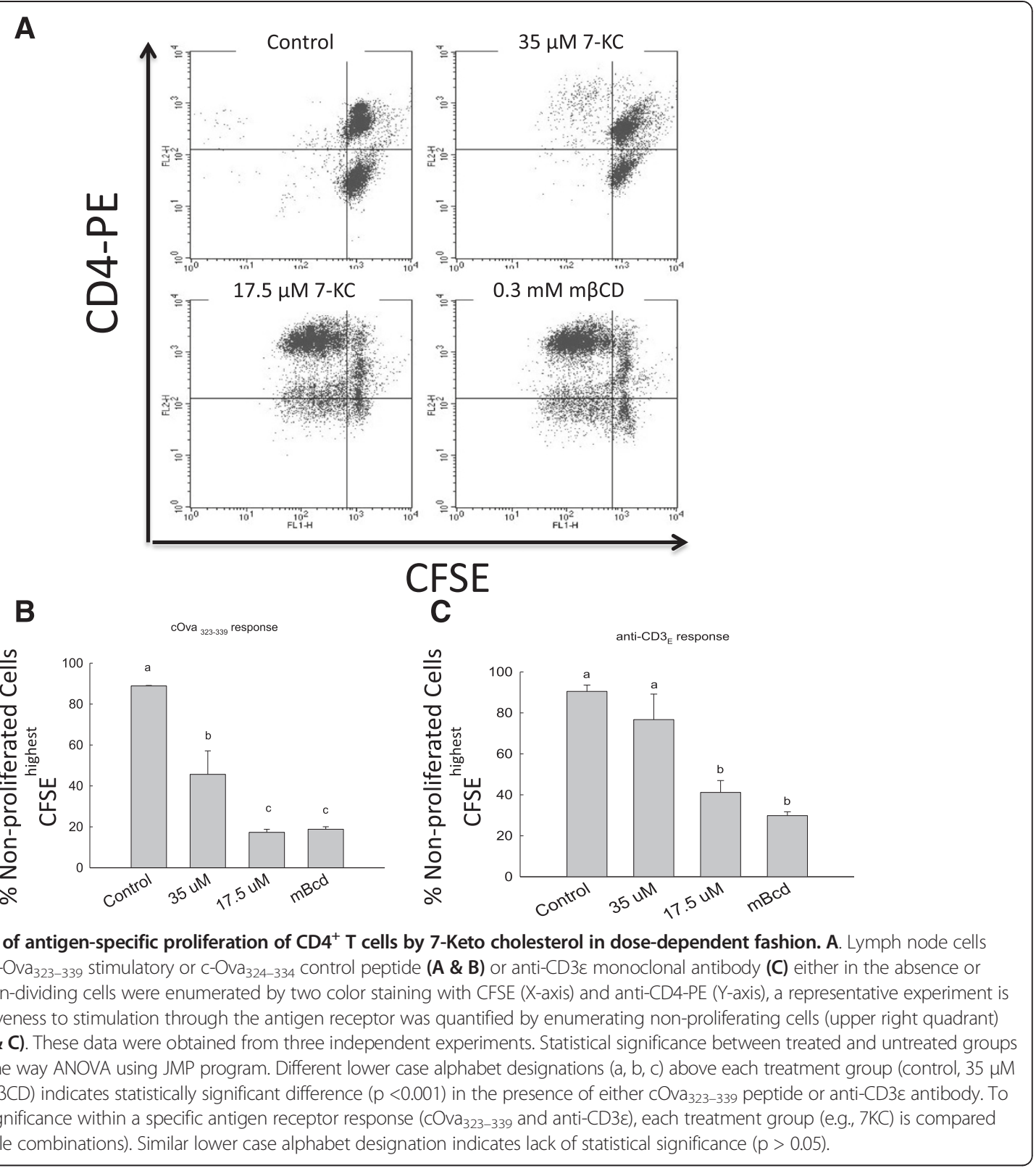

was observed in cultures with $70 \mu \mathrm{M}$ and $35 \mu \mathrm{M} 7-\mathrm{KC}$. These inhibitory effects were specific as the cytokines produce in cultures with vehicle control, $\mathrm{m} \beta \mathrm{CD}$, generated similar levels of cytokines as cell that were not treated with 7-KC.

To examine the specificity of 7-KC treatment on clonal expansion of $\mathrm{CD} 4^{+} \mathrm{T}$ cells we assessed the viability of day3 cell cultures. Figure 5 shows that cells treated with lower $7-\mathrm{KC}$ concentrations $(35 \& 17.5 \mu \mathrm{M})$ did not affect cell viability (Figure 5A-B) compared to cells treated with $\mathrm{COVA}_{324-334}$ control peptide alone or treated with vehicle control $(\mathrm{m} \beta \mathrm{CD})$, but the clonal expansion of $\mathrm{CD}_{4}^{+} \mathrm{T}$ cells

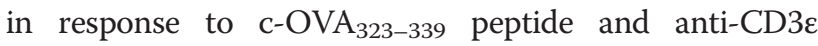
monoclonal antibody was significantly reduced in the presence of $35 \mu \mathrm{M} 7-\mathrm{KC}$ (Figure 4). Reduced viability of normal $\mathrm{CD} 4^{+} \mathrm{T}$ cells in controls on prolonged cell culture is well known and previously documented by us as well [49]. Taken together these data suggest that disruption of lipid raft-based membrane order with insertion of 7-KC in the membrane inhibits antigen receptor-driven clonal expansion of $\mathrm{CD} 4^{+} \mathrm{T}$ cells and cytokine production without compromising the viability of the cells.

Role of lipid raft-based membrane order in the temporal sequence of $\mathrm{CD}^{+} \mathrm{T}$ cell clonal expansion

We next sought to test the time at which 7-KC exerted its effect on $\mathrm{CD} 4^{+} \mathrm{T}$ cell clonal expansion in response to a specific antigen. The early events within seconds and 


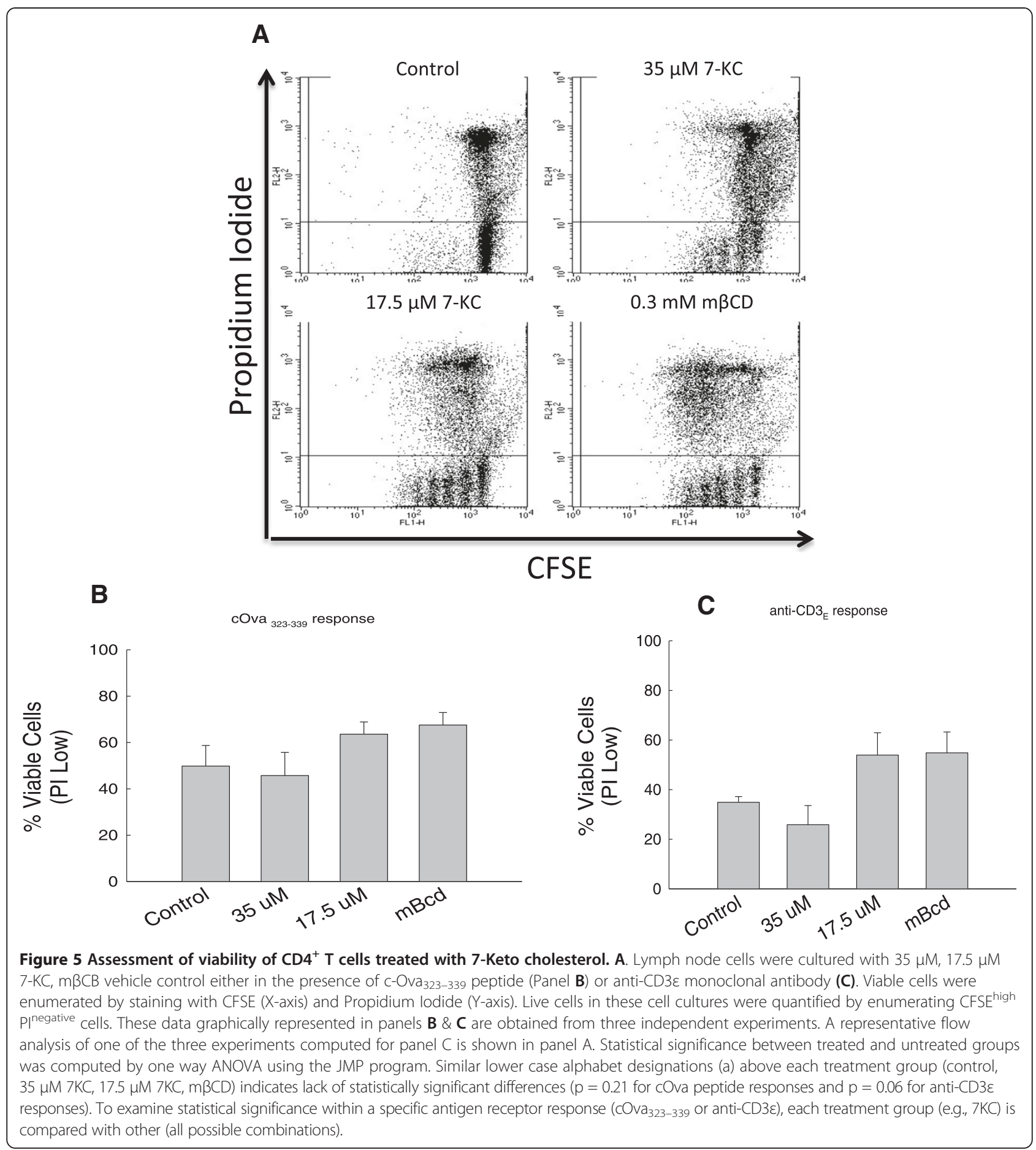

minutes of engagement of the antigen receptor are associated with activation of membrane kinases and phosphorylation events as well as generation of secondary messengers. The later events (after gene transcription) are associated with mitosis primarily driven by the growth factor IL-2. To examine whether the presence of 7-KC affected clonal expansion by altering lipid raftbased membrane order at an early or later phase of clonal expansion, we added this compound at different time points after engaging the antigen receptor. Figure 6A and $C$ \& Additional file 2: Figure S2 show that addition of $7-\mathrm{KC}$ at 5 minute time point after the cultures were set up. Addition of $7-\mathrm{KC}$ at these time points dramatically inhibited the clonal expansion of $\mathrm{CD}^{+} \mathrm{T}$ cells. In the presence of $35 \mu \mathrm{M} 7-\mathrm{KC}$ (a concentration at which the viability of $\mathrm{CD}^{+} \mathrm{T}$ cells is not affected) we observed 


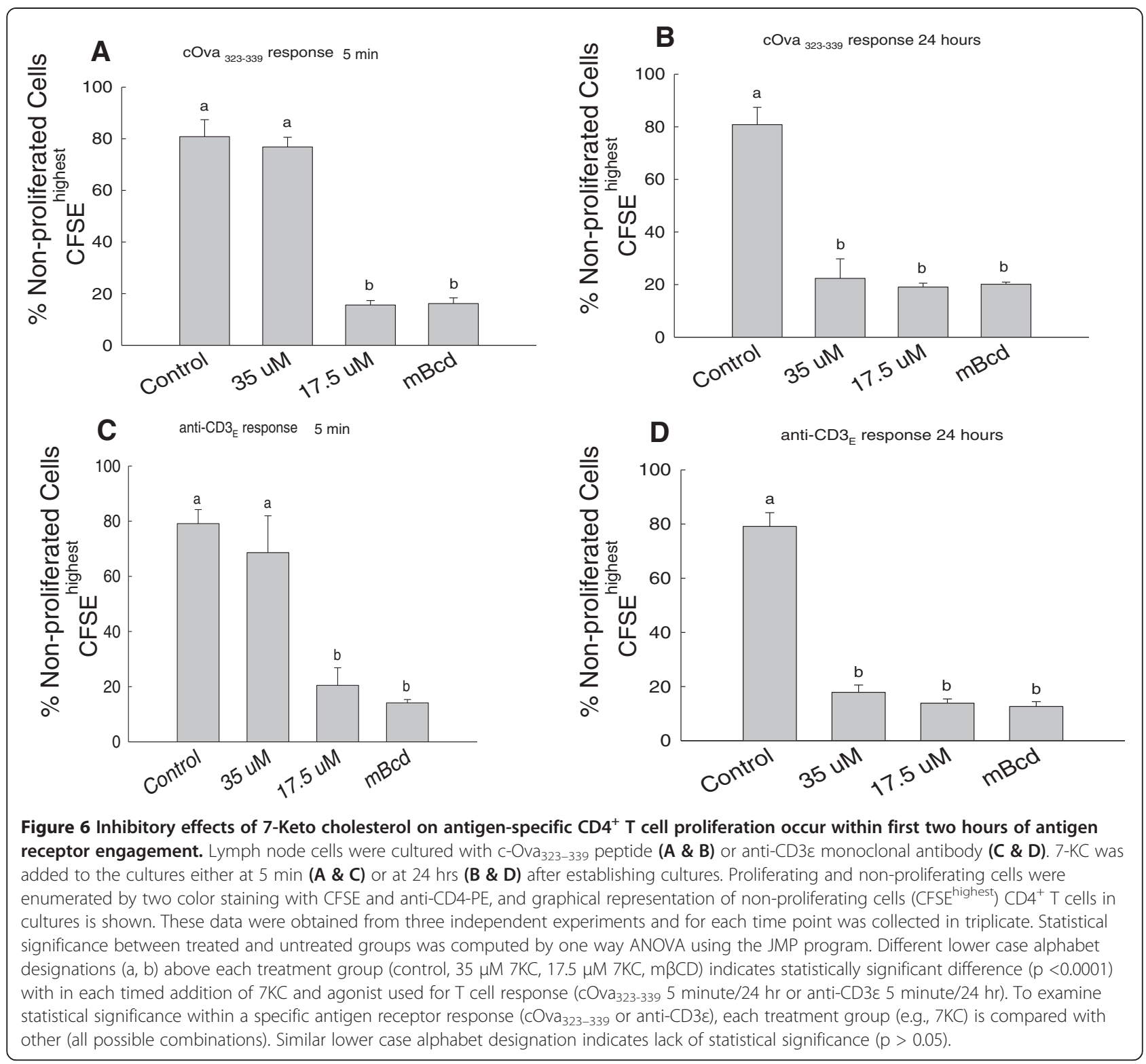

significant reduction in clonal expansion of $\mathrm{CD}^{+}{ }^{+} \mathrm{T}$ cells in response to stimulation through the antigen receptor. Quantifying day-3 cell cultures that were set-up in the presence of $35 \mu \mathrm{M} 7-\mathrm{KC}$ indicated that about $80 \%$ and $70 \%$ of $\mathrm{CD}^{+}$cells remained unresponsive (not undergone cell division) to $\mathrm{c}-\mathrm{OVA}_{323-339}$ peptide and anti-CD3ع, respectively (Figure 6A and $\mathrm{C} \&$ Additional file 2: Figure S2A \& B) which was similar to the control cultures set up with control $\mathrm{cOVA}_{324-334}$ peptide (Figure 6A \& Additional file 2: Figure S2A) or left untreated (Figure 6C \& Additional file 2: Figure S2B) showing approximately $80 \%$ $\mathrm{CD} 4{ }^{+} \mathrm{CFSE} \mathrm{highest}^{\text {high }}$ non-proliferating cells. Proportionally lower inhibition was observed with $17.5 \mu \mathrm{M}$ 7-KC with about $15 \%$ and $20.5 \%$ of non-divided cells remaining in the cultures with $\mathrm{cOva}_{323-339}$ peptide and anti-CD3 $\varepsilon$ antibody stimulated cells respectively. Fraction of nonproliferating cells in the cultures was not significantly different from the cultures stimulated with $\mathrm{COVA}_{323-339}$ in the presence (Figure 6A and C \& Additional file 2: Figure S2) or absence (data not shown) of vehicle $\mathrm{m} \beta \mathrm{CD}$. Similar results were obtained when $7-\mathrm{KC}$ was added at 2 hours after initiating the co-cultures (Additional file 2: Figure S2). In contrast, addition of $7-\mathrm{KC}$ at $24 \mathrm{hrs}$ time point after the engagement of antigen receptor did not affect clonal expansion of $\mathrm{CD}^{+} \mathrm{T}$ cells (Figure $6 \mathrm{~B}$ and $\mathrm{D} \&$ Additional file 2: Figure S2). These results suggest that intactness of membrane order is critical during early signaling events. Taken together, these data suggest that lipid raft-based 
membrane order contributes to clonal expansion during the early phase (occurring within $2 \mathrm{hrs}$.) of the response triggered through engagement of the antigen receptor.

\section{Disrupting lipid raft-based membrane order by incorporating 7-KC in $\mathrm{CD}^{+} \mathrm{T}$ cells is sufficient to inhibit their clonal expansion in response to $\mathrm{COVA}_{323-339}$} Next we sought to examine if lipid raft-based order specifically on the plasma membrane $\mathrm{CD} 4^{+} \mathrm{T}$ cells contributed to diminished clonal expansion of these cells in response to antigen. To test this we incorporated $7-\mathrm{KC}$ in the membrane of purified $\mathrm{CD}^{+} \mathrm{T}$ cells for brief period (excess of $7-\mathrm{KC}$ was removed) and tested their clonal expansion in response to c-OVA $323-339$ presented by APCs that were not exposed to $7-\mathrm{KC}$. Brief treatment (15 min) with $7-\mathrm{KC}$ allowed us to examine the effects of 7 - $\mathrm{KC}$ at higher concentration $(70 \mu \mathrm{M})$. Figure 7 shows that $\mathrm{CD}^{+} \mathrm{T}$ cells with 7 - KC incorporated in the plasma membrane showed reduced clonal expansion in a dosedependent fashion. A maximum effect was observed with $70 \mu \mathrm{M}$ of $7-\mathrm{KC}$ and minimal inhibition. As much as, $44.2 \%$ of $\mathrm{CD}^{+}{ }^{+} \mathrm{T}$ cells incubated with $70 \mu \mathrm{M} 7-\mathrm{KC}$ and $18 \%$ of $\mathrm{CD}_{4}^{+} \mathrm{T}$ cells incubated with $35 \mu \mathrm{M}$ 7-KC did not proliferate in response to $\mathrm{C}_{-} \mathrm{OVA}_{323-339}$ peptide. In the absence of $7-\mathrm{KC}$ and in the presence of vehicle control $\mathrm{m} \beta \mathrm{CD}$, only $10.6 \%$ and $15 \%$ of $\mathrm{CD}^{+}$cells showed lack of proliferation in the $\mathrm{OVA}_{323-339}$ stimulated cultures (Figure 7). These data indicate that disturbance of membrane order on $\mathrm{CD}^{+}{ }^{+} \mathrm{T}$ cell membrane contributes to their diminished clonal expansion in response to the antigen receptor.

\section{Discussion}

Asymmetrical distribution of lipids with in the membrane bilayer and their organization in association with or without membrane proteins into nano-domains (lipid rafts) are the two fundamental properties of the plasma membrane. Lipid raft nano-structures enriched in cholesterol, saturated lipids, and lipid-modified signaling proteins that assemble into dynamic, compositionally heterogeneous nano-domains similar to the liquid order $\left(\mathrm{I}_{\mathrm{o}}\right)$ phase observed with model membranes [55]. These assemblies of proteins and lipids, because of the heterogeneity in composition compartmentalize signaling and, contribute to spatial asymmetry of the membrane bilayer, as well. One approach used to assess the role of lipid raft-based order in cell signaling relies on disrupting the membrane order by exposing the cell membrane to cholesterol-binding, raft-destabilizing molecule, M $\beta C D$. A considerable number of published studies where the role of lipid rafts in early signaling events was assessed have used this compound [43,44]. However, concerns related to its effectiveness at high concentrations and its adverse effects on internal $\mathrm{Ca}^{2+}$ stores have remained [45]. More recently, 7-Keto cholesterol was shown to interfere with the

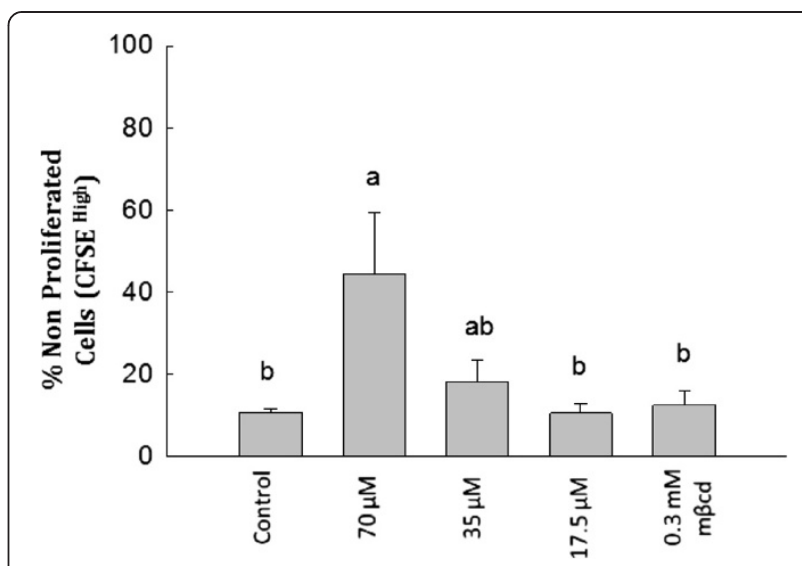

Figure 7 Effect of 7-KC on the proliferation of $\mathrm{CD}^{+} \mathrm{T}$ cell and APC co-cultures where only $\mathrm{CD}^{+} \mathrm{T}$ cells were pre-treated with 7-KC. Purified $\mathrm{CD}^{+} \mathrm{T}$ cells were incubated with 7-KC for 30 minutes at $37^{\circ} \mathrm{C}$ and excess of $7-\mathrm{KC}$ was removed by washing with wash media. CD4 ${ }^{+} T$ cells were stained with CFSE prior to being combined with APCs. 7-KC treated and mock-treated (labeled as control) CD4 ${ }^{+}$

T cells were cultured with c-Ova $\mathrm{O}_{323-339}$ peptide for $72 \mathrm{hrs}$ and stained with anti-CD4 ${ }^{+} \mathrm{PE}$ enumeration of $\mathrm{CD}^{+} \mathrm{T}$ cells only as described in materials and methods section. Proliferating and non-proliferating cells were enumerated by two color staining with CFSE (X-axis) and anti-CD4-PE (Y-axis) and graphical representation of non-proliferating cells (CFSE ${ }^{\text {highest}}$ ) CD4 ${ }^{+} \mathrm{T}$ cells in cultures is shown. These data were obtained from three independent experiments and each 7-KC concentration was carried out in triplicates. Statistical significance between treated and untreated groups was computed by one way ANOVA using JMP program. Different small alphabet designations above each bar indicate statistically significant differences $(p<0.0221)$. Different lower case alphabet designations $(a, b, c)$ above each treatment group (control, $35 \mu \mathrm{M} 7 \mathrm{KC}, 17.5 \mu \mathrm{M} 7 \mathrm{KC}, \mathrm{m} \beta C \mathrm{CD}$ ) indicates statistically significant difference $(p<0.0221)$ in response to either $\mathrm{COva}_{323-339}$ peptide or anti-CD3 $\varepsilon$ antibody. To examine statistical significance within a specific antigen receptor response ( $\mathrm{COva}_{323-339}$ or anti-CD3ع), each treatment group (e.g., 7KC) is compared with other (all possible combinations). Similar lower case alphabet designation indicates lack of statistical significance $(p>0.05)$. Double designation (ab) indicates lack of statistical significance with experimental treatments with designations "a" as well as "b".

lipid raft-based membrane order in immortalized cells $[41,50,56]$. Incorporation of $7-\mathrm{KC}$ resulted in de-condensing of the plasma membrane at the immunological synapse at immortalized $\mathrm{CD}^{+} \mathrm{T}$ cell line - APC interface [50]. These findings using immortalized $\mathrm{T}$ cell line are consistent with early observations related to the effectiveness of $7-\mathrm{KC}$ in preventing the formation of $\mathrm{L}_{\mathrm{o}}$ domains in a model membrane $[57,58]$. However, the role of lipid raft-based membrane order in clonal expansion of primary $\mathrm{CD}^{+} \mathrm{T}$ cells has not been examined. Moreover, the role of foreign antigen in driving this clonal expansion is unknown. We have used $\mathrm{CD}_{4}^{+} \mathrm{T}$ cells from c-OVA $323-339$-peptide specific $\mathrm{T}$ cell receptor transgenic mice to examine this question. We observed that $7-\mathrm{KC}$ inhibited $\mathrm{CD}_{4}^{+} \mathrm{T}$ cell proliferation and IFN- $\gamma$ cytokine production in response to $\mathrm{c}-\mathrm{OVA}_{323-339}$ peptide in a concentration dependent manner. 
Direct insertion of $7-\mathrm{KC}$ in the membrane can alter raft-based membrane order by destabilizing the membrane ordered phase. The presence of the carbon $7 \mathrm{ke}$ tone group on $7-\mathrm{KC}$ prevents the tight packing of saturated acyl chains needed for the formation of the $L_{o}$ phase as observed in model membranes. Consistent with this idea was the observation that $7-\mathrm{KC}$ altered membrane order when assessed with di-4 ANEPPDHQ. In addition, the antibody FRET experiments we observed a significant decrease in FRET signal between CD3 $\varepsilon$ and Thy-1 in the plasma membrane of cells treated with $7-\mathrm{KC}$ indicated an altered membrane fluidity. It is also likely that insertion of $7-\mathrm{KC}$ in the membrane breaks spatial asymmetry and compartmentalization of signaling receptors that negatively impacts early membrane proximal cell signaling events and in turn on the clonal expansion of $\mathrm{CD}^{+} \mathrm{T}$ cells in response to a specific antigen.

Antigen-driven clonal expansion of $\mathrm{CD}^{+} \mathrm{T}$ cells can be viewed to occur in two major phases. In the first phase peptide and MHC class II recognition by the antigen receptor, along with the interaction of a plethora of accessory cell proteins, results in $\mathrm{CD}^{+} \mathrm{T}$ cell activation. The activated $\mathrm{CD}^{+}{ }^{+} \mathrm{T}$ cells generate IL-2, a growth factor for $\mathrm{T}$ cells. In the second phase the IL-2 driven clonal expansion occurs. Previous reports investigating the role of lipid rafts using $M \beta C D$ in $T$ cell signaling had suggested that disruption of lipid rafts interferes in the association of a number of key kinases to the lipid raft $[43,44]$. Our timing experiments where clonal expansion of $\mathrm{CD}^{+} \mathrm{T}$ cell is the final read-out suggests that disruption of membrane order exerts its effect during the CD4 ${ }^{+}$ $\mathrm{T}$ cell activation phase, as significant alteration in clonal expansion of these cells was not observed when 7-KC was added to the cell cultures $24 \mathrm{hrs}$ after engaging the antigen receptor. Our data with primary $\mathrm{CD}^{+} \mathrm{T}$ lymphocytes shows that 7-KC possibly alters the association or stability of signaling complexes during early phases of $\mathrm{T}$ cell activation. Alternatively, destabilizing lipid rafts by incorporating 7-KC can result in the degradation of Akt and/or disruption of ras nanodomains present in the inner leaflet of the plasma membrane [59-62]. Overall our results are consistent with the observation that subsets of primary $\mathrm{CD}^{+} \mathrm{T}$ cells present in peripheral human blood show functional responses correlating with membrane lipid order. The highest response generated by $\mathrm{CD}^{+} \mathrm{T}$ cells through its TCR was observed with high lipid order and lower responses correlated to cells with low membrane lipid order [52].

Cholesterol has the ability to create order in the lipid bilayer of the plasma membrane in variety of cell types [63]. The rigid structure of the cholesterol molecule allows for tight organization of the bilayer. Above a certain cholesterol threshold level, cholesterol rich (or $\mathrm{L}_{\mathrm{o}}$ ) and cholesterol poor $\left(\mathrm{L}_{\mathrm{d}}\right)$ phases can exist in a membrane, while below this threshold only $\mathrm{L}_{d}$ phases are observed. The presence of cholesterol prevents the deformation of the lipid acyl chains and allows for the movement of small molecules across the bilayer, while lipids can still move freely past each other. Several studies have confirmed these findings by demonstrating that certain levels of cholesterol induce a phase transition. Theoretically, cholesterol levels could be increased to the level where the entire membrane is a lipid ordered phase. A study (independent of the lipid raft hypothesis) by Bensinger et al. in 2008 has demonstrated that cholesterol is critical for $\mathrm{T}$ cell proliferation [64]. Their data showed that disrupting LXR genes, which are involved in the transcriptional regulation of intracellular cholesterol homeostasis, caused a loss of control of the immune response and hyperplasia in affected T cells. These experiments highlight the importance of cholesterol homoeostasis in cell signaling. Consistent with this is the data that by activating LXR results in reduced levels of membrane cholesterol affecting the membrane order [65]. These published data suggest that homoeostasis of cholesterol regulates proliferative potential of $\mathrm{T}$ cells possible by altering cholesterol-dependent membrane order.

One mechanism through which lipid raft-based membrane order may contribute to cell signaling is by promoting proximity between signaling proteins in the membrane, which allows signaling for cell survival in a ligand-independent manner through cell autonomous (external ligand-independent) mechanisms or tonic signaling mechanisms. However, higher order membrane coalescence and compartmentalization of signaling molecules in and out of these aggregated rafts is promoted by specific ligand - receptor interactions in a non-cell autonomous manner. We think that $7-\mathrm{KC}$ disrupts lipid raft-based membrane order and the assembly of lipid rafts during interaction between the interacting $\mathrm{CD}^{+}{ }^{+} \mathrm{T}$ cells and APCs and thereby inhibiting clonal expansion of $\mathrm{CD}^{+} \mathrm{T}$ cells in response to engagement of antigen receptors. Our results also suggest that re-organization of lipid rafts and membrane order has a role in the early part of the $\mathrm{T}$ cell response as opposed to the second phase that is driven by IL-2 binding to the IL-2 receptor. This early signaling is likely to inhibit the gene expression patterns as indicated by inhibition of IFN- $\gamma$ cytokine production by $7-\mathrm{KC}$ - exposed $\mathrm{CD}^{+}{ }^{+} \mathrm{T}$ cells in response to the antigen receptor signaling. Further experiments will be required to directly identify the molecular players at the early stages of $\mathrm{CD}^{+} \mathrm{T}$ cell activation influenced by lipid raft-based membrane order.

\section{Conclusion}

Our findings suggest that lipid raft-based membrane order is critical for clonal expansion of $\mathrm{CD}^{+} \mathrm{T}$ cells in response to a model peptide. 


\section{Additional files}

Additional file 1: Figure S1. 7-Keto cholesterol inhibits production of IFN- $\gamma$ by $C D 4^{+} T$ cells in response to a specific antigen. Lymph node cells were cultured with c-Ova ${ }_{323-339}$ peptide either in the absence or presence of various concentration of 7-KC. Cells exposed to $0.3 \mathrm{mM} \mathrm{m \beta cd}$, (vehicle control) (open inverted triangle), $17.5 \mu \mathrm{M}$ 7-KC (filled diamond), $35 \mu \mathrm{M}$ (open triangle), $70 \mu \mathrm{M}$ (open circle) or left untreated (open square) were stimulated with c-Ova $323-339$ and supernatant was harvested on days 1, 2 and 3 to quantify IFN- $\gamma$ by ELISA (BD Biosciences). Supernatants from cultures stimulated with control peptide, cOva $324-334$ was used as controls (open diamond). A representative data out of total three experiments is shown.

Additional file 2: Figure S2. Inhibitory effects of 7-Keto cholesterol on antigen-specific $\mathrm{CD}^{+} \mathrm{T}$ cell proliferation occur within first two hours of antigen receptor engagement. Lymph node cells were labeled with CFSE and cultured with c-Ova $323-339$ peptide (A) or anti-CD3ع monoclonal antibody (B). 7-KC was added to the cultures either at $5 \mathrm{~min}, 2 \mathrm{hrs}$ or at $24 \mathrm{hrs}$ after establishing cultures as indicated in each panel. Proliferating and non-proliferating cells were enumerated by two color analyses with CFSE (FL1) and anti-CD4-PE (FL2). A representative graphs from three independent experiments and for each time point collected in triplicate is shown and quantification of these data for 5 minute and $24 \mathrm{hr}$ time points is shown in Figure 7. Co-culture groups were treated with cOva324-334 peptide (panel A) or left untreated (B). Majority of CD4 ${ }^{+} \mathrm{T}$ cells (approximately $80 \%$ ) remain non-proliferated under these conditions.

\section{Abbreviations}

CD4: Cluster differentiation antigen 4; APC: Antigen presenting cell; 7-KC: 7-ketocholesterol; GPI: Glycosylphosphotidyl-inositol; TCR: T cell receptor; Th: T helper cell; $I_{\mathrm{o}}$ : Lipid ordered phase; $I_{\mathrm{d}}$ : Lipid disordered phase.

\section{Competing interests}

The authors declare that they have no competing interests.

\section{Authors' contributions}

DS SN and WB performed experiments, analyzed the data, performed the statistical analysis and partly wrote the manuscript, AKB performed experiments for Figure 3, designed the project, coordinated the project, analyzed the data generated by DS SN and WB, wrote the manuscript and edited the manuscript. All authors have read and approved the manuscript.

\section{Acknowledgements}

This work was supported by SRFG \& SRG grants from Office of Research and Sponsored Projects (ORSP), Villanova University and Department of Biology, Villanova University. This work was also supported by Graduate Program, Department of Biology to DS and Center for Undergraduate Research and Fellowship to (SN) at Villanova University. We thank Dr. David Lo for providing D011 T cell receptor transgenic mice and Dr. Jan Knepper for providing Balb/c mice. We thank Drs. Matthew Youngman and Jim Wilson for providing valuable comments and to Dr. Michael Russell for help with statistical analyses.

\section{Author details}

${ }^{1}$ Department of Biology, Villanova University, 800 Lancaster Avenue, Villanova, PA 19085, USA. ${ }^{2}$ Current Address: DeNovix Inc, Wilmington, DE 19808, USA. ${ }^{3}$ Current Address: M.D. Program, Drexel University, 3141 Chestnut Street, Philadelphia, PA 19104, USA.

Received: 21 March 2014 Accepted: 24 November 2014

Published online: 14 December 2014

\section{References}

1. Singleton $K L$, Roybal KT, Sun Y, Fu G, Gascoign NR, van Oers NS, Wülfing C: Spatiotemporal patterning during $\mathrm{T}$ cell activation is highly diverse. Sci Signal 2009, 2:ra15.

2. Bamezai A: Lipid rafts and signaling. Immunol Endo and Met Agents in Med Chem 2008, 8:325-326.

3. Kholodenko BN, Hancock JF, Kolch W: Signaling ballet in space and time. Nat Rev Mol Cell Biol 2010, 11:414-426.
4. Dehmelt L, Bastiaens PI: Spatial organization of intracellular communication: insights from imaging. Nat Rev Mol Cell Biol 2010, 11:440-452.

5. Yang G: Bioimage informatics for understanding spatiotemporal dynamics of cellular processes. Wiley Interdiscip Rev Syst Biol Med 2013, 5:367-380

6. Hinde E, Digman MA, Hahn KM, Gratton E: Millisecond spatiotemporal dynamics of FRET biosensors by the pair correlation function and the phasor approach to FLIM. Proc Natl Acad Sci U S A 2013, 110:135-140.

7. Chentouf $M$, Ghannam S, Bès $C$, Troadec $S$, Cérutti M, Chardès T: Recombinant anti-CD4 antibody $13 \mathrm{~B} 8.2$ blocks membrane-proximal events by excluding the Zap70 molecule and downstream targets SLP-76, PLC gamma 1, and Vav-1 from the CD4-segregated Brij 98 detergent-resistant raft domains. J Immunol 2007, 179:409-420.

8. Bretscher MS: Asymmetrical lipid bilayer structure for biological membranes. Nat New Biol 1972, 236:11-12.

9. Gordesky SE, Marinetti GV: The asymetric arrangement of phospholipids in the human erythrocyte membrane. Biochem Biophys Res Commun 1973, 50:1027-1031

10. Verkleij AJ, Post JA: Membrane phospholipid asymmetry and signal transduction. J Membr Biol 2000, 178:1-10.

11. van Meer G, Voelker DR, Feigenson GW: Membrane lipids: where they are and how they behave. Nat Rev Mol Cell Biol 2008, 9:112-124.

12. Leventis PA, Grinstein S: The distribution and function of phosphatidylserine in cellular membranes. Annu Rev Biophys 2010, 39:407-427.

13. Vyas KA, Patel HV, Vyas AA, Schnaar RL: Segregation of gangliosides GM1 and GD3 on cell membranes, isolated membrane rafts, and defined supported lipid monolayers. Biol Chem 2001, 382:241-250.

14. Schade $A E$, Levine $A D$ : Lipid raft heterogeneity in human peripheral blood T lymphoblasts: a mechanism for regulating the initiation of TCR signal transduction. J Immunol 2002, 168:2233-2239.

15. Marwali MR, Rey-Ladino J, Dreolini L, Shaw D, Takei F: Membrane cholesterol regulates LFA-1 function and lipid raft heterogeneity. Blood 2003, 102:215-222.

16. Pike LJ: Lipid rafts: heterogeneity on the high seas. Biochem J 2004, 378:281-292.

17. George S, Nelson MD, Dollahon N, Bamezai A: A novel approach to examining compositional heterogeneity of detergent-resistant lipid rafts. Immunol Cell Biol 2006, 84:192-202.

18. Jacobson K, Mouritsen OG, Anderson RG: Lipid rafts: at a crossroad between cell biology and physics. Nat Cell Biol 2007, 9:7-14.

19. Sohn HW, Tolar P, Pierce SK: Membrane heterogeneities in the formation of $B$ cell receptor-Lyn kinase microclusters and the immune synapse. J Cell Biol 2008, 182:367-379.

20. Karnovsky MJ, Kleinfeld AM, Hoover RL, Klausner RD: The concept of lipid domains in membranes. J Cell Biol 1982, 94:1-6.

21. Lingwood D, Simons K: Lipid rafts as a membrane-organizing principle. Science 2010, 327:46-50.

22. Kenworthy AK, Edidin E: Distribution of a glycosylphosphatidylinositolanchored protein at the apical surface of MDCK cells examined at a resolution of $<100 \mathrm{~A}$ using imaging fluorescence resonance energy transfer. J Cell Biol 1998, 142:69-84.

23. Brown A, London E: Functions of lipid rafts in biological membranes Annu Rev Cell Dev Biol 1998, 14:111-136.

24. Sengupta P, Baird B, Holowka D: Lipid rafts, fluid/fluid phase separation, and their relevance to plasma membrane structure and function. Semin Cell Dev Biol 2007, 18:583-590.

25. Mazza C, Malissen B: What guides MHC-restricted TCR recognition? Semin Immunol 2007, 19:225-235.

26. Rudolph MG, Stanfield RL, Wilson IA: How TCRs bind MHCs, peptides, and coreceptors. Annu Rev Immunol 2006, 24:419-466.

27. Smith-Garvin JE, Koretzky GA, Jordan MS: T Cell Activation. Annu Rev Immunol 2009, 27:591-619.

28. Monks CR, Freiberg BA, Kupfer H, Sciaky N, Kupfer A: Three-dimensional segregation of supramolecular activation clusters in T cells. Nature 1998 395:82-86.

29. Grakoui A, Bromley SK, Sumen C, Davis MM, Shaw AS, Allen PM, Dustin ML: The immunological synapse: a molecular machine controlling $T$ cell activation. Science 1999, 285:221-227.

30. Burack WR, Lee KH, Holdorf AD, Dustin ML, Shaw AS: Cutting edge: quantitative imaging of raft accumulation in the immunological synapse. $\mathrm{J}$ Immunol 2002, 169:2837-2841. 
31. Hiltbold EM, Poloso NJ, Roche PA: MHC class II-peptide complexes and APC lipid rafts accumulate at the immunological synapse. J Immunol 2003, 170:1329-1338.

32. Shirakawa J, Wang Y, Tahara-Hanaoka S, Honda S, Shibuya K, Shibuya A: LFA-1-dependent lipid raft recruitment of DNAM-1 (CD226) in CD4+ T cell. Int Immunol 2006, 18:951-957.

33. Tavano R, Contento RL, Baranda SJ, Soligo M, Tuosto L, Manes S, Viola A: CD28 interaction with filamin-A controls lipid raft accumulation at the T-cell immunological synapse. Nat Cell Biol 2006, 8:1270-1276.

34. Van Komen JS, Mishra S, Byrum GR, Chichili JC, Yaciuk A, Farris D, Rodgers W: Early and dynamic polarization of T cell membrane rafts and constituents prior to TCR stop signals. J Immunol 2007, 179:6845-6855

35. Zech T, Ejsing CS, Gaus K, de Wet B, Shevchenko A, Simons K, Harder T: Accumulation of raft lipids in T-cell plasma membrane domains engaged in TCR signalling. EMBO J 2009, 28:466-476.

36. Dart C: Lipid microdomains and the regulation of ion channel function. J Physio/ 2010, 588:3169-3178.

37. Pani B, Singh BB: Lipid rafts/caveolae as microdomains of calcium signaling. Cell Calcium 2009, 45:625-633.

38. Li H, Ayer LM, Lytton J, Deans JP: Store-operated cation entry mediated by CD20 in membrane rafts. J Biol Chem 2003, 278:42427-42434

39. Janes PW, Ley SC, Magee Al, Kabouridis PS: The role of lipid rafts in T cell antigen receptor (TCR) signalling. Semin Immunol 2000, 12:23-34.

40. Viola A: The amplification of TCR signaling by dynamic membrane microdomains. Trends Immunol 2001, 22:322-327.

41. Martinez-Seara H, Róg T, Karttunen M, Vattulainen I, Reigada R: Cholesterol induces specific spatial and orientational order in cholesterol/ phospholipid membranes. PLoS One 2010, 5:e11162

42. Kennedy C, Nelson MD, Bamezai AK: Analysis of detergent-free lipid rafts isolated from CD4+ T cell line: interaction with antigen presenting cells promotes coalescing of lipid rafts. Cell Commun Signal 2011, 9:e31.

43. Xavier R, Brennan T, Li Q, McCormack C, Seed B: Membrane compartmentation is required for efficient T cell activation. Immunity 1998, 8:723-732

44. Montixi C, Langlet C, Bernard AM, Thimonier J, Dubois C, Wurbel MA, Chauvin JP, Pierres M, He HT: Engagement of T cell receptor triggers its recruitment to low-density detergent-insoluble membrane domains. EMBO J 1998, 17:5334-5348.

45. Munro S: Lipid rafts: elusive or illusive? Cell 2003, 115:377-388.

46. Shaw AS: Lipid rafts: now you see them, now you don't. Nat Immunol 2006, 7:1139-1142

47. Mahammad S, Parmryd I: Cholesterol homeostasis in T cells. Methyl-betacyclodextrin treatment results in equal loss of cholesterol from Triton X-100 soluble and insoluble fractions. Biochim Biophys Acta 2008, 1778:1251-1258.

48. Murphy KM, Heimberger AB, Loh DY: Induction by antigen of intrathymic apoptosis of $\mathrm{CD}^{+}{ }^{+} \mathrm{CD}^{+}{ }^{+} \mathrm{TCR}^{\text {lo }}$ thymocytes in vivo. Science 1990 , 250:1720-1723.

49. Reed J, Branigan $P$, Bamezai A: Interferon- $\gamma$ enhances clonal expansion and survival of CD4 ${ }^{+}$T cells. J Interferon Cytokine Res 2008, 28:611-622.

50. Rentero C, Zech T, Quinn CM, Engelhardt K, Williamson D, Grewal T, Jessup W, Harder T, Gaus K: Functional implications of plasma membrane condensation for T cell activation. PLoS One 2008, 3:e2262.

51. Banning C, Votteler J, Hoffmann D, Koppensteiner H, Warmer M, Reimer R, Kirchhoff F, Schubert U, Hauber J, Schindler M: A Flow Cytometry-Based FRET Assay to Identify and Analyse Protein-Protein Interactions in Living Cells. PLoS One 2010, 5:e9344

52. Miguel L, Owen DM, Lim C, Liebig C, Evans J, Magee Ml, Jury EC: Primary human CD4+ T cells have diverse levels of membrane lipid order that correlate with their function. J Immunol 2011, 186:3505-3516.

53. Harder T, Scheiffele P, Verkade $P$, Simons K: Lipid domain structure of the plasma membrane revealed by patching of membrane components. J Cell Biol 1998, 141:929-942.

54. Jin L, Millard AC, Wuskell JP, Clark HA, Loew LM: Cholesterol enriched lipid domains can be visualized by di4ANEPPDHQ with linear and nonlinear optics. Biophys J 2005, 89:L04-6.

55. Silvius JR: Partitioning of membrane molecules between raft and non-raft domains: insights from model-membrane studies. Biochim Biophys Acta 2005, 1746:193-202.

56. Massey JB, Pownall HJ: The polar nature of 7-ketocholesterol determines its location within membrane domains and the kinetics of membrane microsolubilization by apolipoprotein A-I. Biochemistry 2005, 44:10423-10433.

57. Mintzer E, Charles G, Gordon S: Interaction of two oxysterols, 7-ketocholesterol and 25-hydroxycholesterol, with phosphatidylcholine and sphingomyelin in model membranes. Chem Phys Lipids 2010, 163:586-593.

58. Royer MC, Lemaire-Ewing S, Desrumaux C, Monier S, Pais de Barros JP, Athias A, Néel D, Lagrost L: 7-ketocholesterol incorporation into sphingolipid/cholesterol-enriched (lipid raft) domains is impaired by vitamin E: a specific role for alpha-tocopherol with consequences on cell death. J Biol Chem 2009, 284:15826-15834.

59. Gao X, Zhang J: Spatiotemporal analysis of differential Akt regulation in plasma membrane microdomains. Mol Biol Cell 2008, 19:4366-4373.

60. Liu J, Netherland C, Pickle T, Sinensky MS, Thewke DP: Stimulation of Akt poly-ubiquitination and proteasomal degradation in P388D1 cells by 7-ketocholesterol and 25-hydroxycholesterol. Arch Biochem Biophys 2009, 487:54-58.

61. Bauer B, Jenny M, Fresser F, Uberall F, Baier G: AKT1/PKBalpha is recruited to lipid rafts and activated downstream of PKC isotypes in CD3-induced T cell signaling. FEBS Lett 2003, 541:155-162.

62. Lasserre R, Guo XJ, Conchonaud F, Hamon Y, Hawchar O, Bernard AM, Soudja SM, Lenne PF, Rigneault $H$, Olive D, Bismuth $G$, Nunès JA, Payrastre $B$, Marguet D, He HT: Raft nanodomains contribute to Akt/PKB plasma membrane recruitment and activation. Nat Chem Biol 2008, 4:538-547.62.

63. Mouritsen OG, Zuckermann MJ: What's so special about cholesterol? Lipids 2004, 39:1101-1113.

64. Bensinger SJ, Bradley MN, Joseph SB, Zelcer N, Janssen EM, Hausner MA, Shih R, Parks JS, Edwards PA, Jamieson BD, Tontonoz P: LXR signaling couples sterol metabolism to proliferation in the acquired immune response. Cell 2008, 134:97-111.

65. Aye IL, Waddell BJ, Mark PJ, Keelan JA: Placental ABCA1 and ABCG1 transporters efflux cholesterol and protect trophoblasts from oxysterol induced toxicity. Biochim Biophys Acta 2010, 1801:1013-1024.

doi:10.1186/s12865-014-0058-8

Cite this article as: Schieffer et al:: Lipid raft-based membrane order is important for antigen-specific clonal expansion of $\mathrm{CD}^{+} \mathrm{T}$ lymphocytes. BMC Immunology 2014 15:58.

\section{Submit your next manuscript to BioMed Central and take full advantage of:}

- Convenient online submission

- Thorough peer review

- No space constraints or color figure charges

- Immediate publication on acceptance

- Inclusion in PubMed, CAS, Scopus and Google Scholar

- Research which is freely available for redistribution 